\title{
INTEGRATED STATISTICAL METHODOLOGY FOR OPTIMIZING THE MACHINING PARAMETERS IN SiC POWDER MIXED - EDDSG PROCESS TO MACHINE Ti6Al4V
}

\author{
INTEGRIRANA STATISTIČNA METODOLOGIJA ZA \\ OPTIMIZIRANJE PARAMETROV BRUŠENJA POVRŠINE Ti6A14V \\ ZLITINE Z EDDSG PROCESOM V MEŠANICI S SiC PRAHOM
}

\author{
Manoj Modi ${ }^{*}$, Gopal Agarwal ${ }^{2}$ \\ ${ }^{1}$ Department of Mechanical Engineering, Acropolis Institute of Technology and Research, Indore, India \\ ${ }^{2}$ Department of Mechanical Engineering, Malaviya National Institute of Technology, Jaipur, Rajasthan, India
}

Prejem rokopisa - received: 2018-09-07; sprejem za objavo - accepted for publication: 2018-12-17

doi: $10.17222 /$ mit.2018.194

\begin{abstract}
The objective of this research work was targeted to investigate the hybrid-statistical methodology to deduce the economicalmachining-condition through multi-output optimization in silicon carbide powder mixed-Electro Discharge Diamond Surface Grinding of Ti6Al4V. In this work, Grey-Fuzzy based principal component analysis along with Taguchi's orthogonal array is utilised for the multi-output optimization of hybrid-machining process parameters for minimal surface roughness, minimal wheel-wear rate, and maximal material removal rate. Eighteen experiments have been conducted according to Taguchi's $\mathrm{L}_{18}$ orthogonal array on in-house-designed and fabricated powder mixed-Electro Discharge Diamond Surface Grinding set-up. The single Multi-Output Performance Index is calculated by the aggregation of all multi-responses by using Grey-Fuzzy-Taguchi method based principal component analysis function. The optimum combination of process parameters and the effect of these parameters on the Multi-Output Performance Index are determined by the use of ANOVA analysis and response table. For the validation test, one additional confirmation experiment is conducted on this set-up according to the derived optimal condition and the outcomes of the results showed satisfactory matching between the predicted and experimented result. The specific contribution of this research work is to develop and describe the procedure of integrated statistical methodology for multi-output optimization of machining parameters in powder mixed-Electro Discharge Diamond Surface Grinding of Ti6Al4V. This integrated statistical approach hybridizes the concepts of Grey Relational Analysis, Fuzzy, principal component analysis and Taguchi approach to find the optimum combination of machining parameters for economical machining. This optimum combination of process parameters supports engineers to establish an economical and effective process.

Keywords: analysis of variance (ANOVA), powder mixed-electro discharge diamond surface grinding (PM-EDDSG), hybrid process, grey relational analysis, fuzzy, principal component analysis (PCA), Taguchi's method (TM), Ti-6Al-4V

Pričujoč članek opisuje raziskavo hibridne statistične metodologije za določitev ekonomičnih pogojev mehanske obdelave z večkomponentno analizo optimizacije izhodnih podatkov brušenja površine Ti6Al4V zlitine s tako imenovanim postopkom PM-EDDSG (diamantno brušenje površine $\mathrm{z}$ elektro erozijo $\mathrm{v}$ mešanici prahu). V tem delu je uporabljena osnovna komponentna analiza, ki temelji na tako imenovani sivo-zabrisani logiki (angl.: Grey-Fuzzy) v kombinaciji s Taguchijevo ortogonalno matriko, s katero naj bi napovedali izhodne pogoje za doseganje minimalne površinske hrapavosti, minimalne obrabe brusilnega koluta in maksimalno hitrost odstranjevanja materiala pri hibridni mehanski obdelavi s PM-EDDSG postopkom. Avtorji so izvedli osemnajst eksperimentov v skladu s Taguchijevo $\mathrm{L}_{18}$ ortogonalno matriko na doma dizajniranem in izdelanem stroju za PM-EDDSG postopek. Posamezen večizhodni indeks učinkovitosti (MOPI; angl.: Multi-Output Performance Index) so izračunali z združitvijo vseh večkratnih odzivov in z uporabo G-F-T metode (angl.: Grey-Fuzzy-Taguchi method), ki temelji na komponentni funkcijski analizi. Optimalno kombinacijo procesnih parametrov in vpliv teh parametrov na MOPI so določili z uporabo ANOVA analize in tabele odzivov. Kot validacijski test so izvedli še en dodatni eksperiment na pričujoči napravi pri dobljenih optimalnih pogojih. Rezultati preizkusa so pokazali zadovoljivo ujemanje med napovedanimi in z eksperimentom dobljenimi rezultati. Specifični prispevek tega raziskovalnega dela je razvoj in opis postopka integrirane statistične metodologije za več izhodno optimizacijo parametrov mehanske obdelave površine Ti6Al4V zlitine s PM-EDDSG postopkom. Ta integrirani statistični pristop združuje koncepte sivo-zabrisane relacijske analize (angl.: Grey-Fuzzy Relational Analysis), osnovne komponentne analize in Taguchijeve metode za določitev optimalne kombinacije procesnih parametrov ekonomične mehanske obdelave. Ta optimalna kombinacija procesnih parametrov omogoča procesnim inženirjem uvajanje
\end{abstract} novega ekonomičnega in učinkovitega procesa.

Ključne besede: analiza variance (ANOVA), diamantno brušenje površine z elektroerozijo v mešanici prahu (PM-EDDSG), hibridni proces, siva relacijska analiza, zabrisanost, osnovna komponentna analiza (PCA), Taguchijeva metoda (TM), Ti-6Al-4V

\section{INTRODUCTION}

Powder Mixed-Electro Discharge Diamond Surface Grinding is an emerging hybrid process for the machining of hard materials like Ti6Al4V. This material is widely utilized in various applications, including bio-

*Corresponding author e-mail: manojmnitjaipur1@gmail.com medical, automotive, etc. Lin et al. ${ }^{1}$ did experimentation on the Electrical Discharge Machining of SKD11 steel and reported that the material removal rate and electrode wear ratio are improved together by using a TaguchiFuzzy logic approach for solving the multi-output optimization problem. Kung et al. $^{2}$ conducted experimentation on Powder Mixed Electrical Discharge Machining of 94WC-6Co and developed the models for material 
removal rate and electrode wear ratio by Response Surface Methodology. Further, they studied the influence of input variables on the responses. Singh et al. ${ }^{3}$ conducted experimentation on the Electro Discharge Face Grinding of WC-Co and studied the influence of process variables over the responses. Lin et $a .^{4}$ carried out experimentation on the Electrical Discharge Machining of SKD11 steel and showed that a combined Grey Relational Analysis-orthogonal array approach enhances the machining performance in multi-output optimization. This combined methodology improves the process outputs, i.e., electrode wear ratio, material removal rate and surface roughness in the Electrical Discharge Machining process. Tarng et al. ${ }^{5}$ carried out experiments and reported the use of the Taguchi approach to find the optimum combination of welding variables in the submerged arc-welding of mild steel plates. Ko et al. ${ }^{6}$ applied a Grey Relational Analysis and the Fuzzy-orthogonal array method on Electrical Discharge Machining, Tzeng et al. ${ }^{7}$ applied the Fuzzy-Taguchi method on Electrical Discharge Machining and Lin et al. ${ }^{8}$ applied Grey-Fuzzy method on Electrical Discharge Machining for the multi-output optimization of process variables. George et al. ${ }^{9}$ applied the Taguchi method to find the optimum combination of process variables on Electrical Discharge Machining of C-C composites. Fung et al. ${ }^{10}$ performed experimental work and presented the use of the principal component analysis-Taguchi approach for the optimization of multi-output in, fiber-reinforced polybutylene terephthalate composites. Alagumurthi et al. ${ }^{11}$ have conducted experimental work on the grinding of mild steel and compared the factorial design of experiment with the Taguchi design of experiment approach, used to find the optimal grinding conditions. They reported that depth of cut, wheel speed and work speed were important grinding parameters that affect the grinding quality. Jean et al. ${ }^{12}$ conducted experimental work and reported the use of a principal component analysis-Taguchi approach to develop a robust Electron Beam Welding Treatment process with high efficiency multiple-performance characteristics (MPCs). Dutta et al. ${ }^{13}$ conducted experimentation on Wire Electrical Discharge Machining of D2 tool steel. They applied Response Surface Methodology to develop the models for each response and these models were used to predict the behaviour of process variables on the responses. They applied Grey Relational Analysis-Taguchi methodology to find the optimal variables setting in multi-response optimization. Lahane et al. ${ }^{14}$ did experimental work and proposed a Weighted Principal Component method for multi-outputs optimization of the process factors in the wire Electrical Discharge Machining of HSS steel. V. K. Jain ${ }^{15}$ reported that Hybrid Machining Process performance is more effective as compared to separate performance of component process with similar input variables.
Based on the above literature review, there is the necessity for efficient optimization methodology to take care of the problems related to the co-occurring optimization of multi-correlated responses and their solutions. Taguchi's methodology has been broadly utilized for process parameters optimization. This technique is beneficial for single response optimization, however, ineffective to optimize the multi-responses. In this research work, Taguchi's method is integrated with Grey-fuzzy based principal component analysis to beat the drawback in managing the difficulty of the simultaneous optimization of multi-correlate responses.

This integrated statistical methodology is utilized to derive an identical equivalent process-quality index by combining the multi-responses to depict the overall quality of the process so that the difficulty of concurrent optimization of multi-responses is substituted by the problem of maximizing the process - Overall Quality Index. That is why Taguchi's Utility-Theory can be efficiently utilized to maximize the process overall quality.

In this research work, a unique integrated multi-output optimization methodology is planned to deduce the optimum combination of machining variables in the Powder Mixed-Electro Discharge Diamond Surface Grinding of Ti6Al4V. This integrated methodology hybridizes the concepts of Grey, Fuzzy, Principal Component-Analysis and Taguchi to take care of the problem of co-occurring optimization of three correlative Powder Mixed-Electro Discharge Diamond Surface Grinding process performance measures like material removal rate, surface roughness, and wheel wear rate in machining of Ti6Al4V.

\section{METHOD FOR MULTI-OUTPUT-OPTIMIZA- TION}

\subsection{Grey Relational Analysis Method}

In Grey Relational Analysis, the initial step is to normalize the experimental data between zero-to-one by using Equations (1) and (2). For material removal rate, the higher is the better criterion is selected. Similarly, for surface roughness and wheel wear rate, the lower is the better criterion has been selected. ${ }^{16}$

For higher is the better criterion (H-T-B),

$$
x_{i}^{*}(t)=\frac{x_{i}^{(0)}(t)-\min x_{i}^{(0)}(t)}{\max x_{i}^{(0)}(t)-\min x_{i}^{(0)}(t)}
$$

For lower is the better criterion (L-T-B),

$$
x_{i}^{*}(t)=\frac{\max x_{i}^{(0)}(t)-x_{i}^{(0)}(t)}{\max x_{i}^{(0)}(t)-\min x_{i}^{(0)}(t)}
$$

where, $x_{i}^{(0)}(t)=$ original sequence, $x_{i}^{(*)}(t)=$ value after the Grey Relational normalization, $\min x_{i}^{(0)}(t)=$ lowest value of $x_{i}^{(0)}(t), \max x_{i}^{(0)}(t)=$ maximum value of $x_{i}^{(0)}(t)$, $i=1,2, \ldots, p ; t=1,2, \ldots, q, p=$ total experiment and $q=$ 
total observation data. The next step is to determine the deviation sequence $\left[\Delta_{o i}(t)\right]$ for every output $(\zeta=0.5)$ and then the Grey Relational Coefficient is determined by using Equation (3).

$$
\begin{gathered}
\gamma\left(x_{o}^{*}(t), x_{i}^{*}(t)\right)=\frac{\Delta_{\min }+\zeta \Delta_{\max }}{\Delta_{o i}(t)+\zeta \Delta_{\max }} \\
0<\gamma\left(x_{o}^{*}(t), x_{i}^{*}(t)\right) \leq 1, \quad \Delta_{o i}(t)=\left|x_{o}^{*}(t), x_{i}^{*}(t)\right|, \\
\Delta_{\max }=\max _{\forall j \in i} \max _{\forall t}\left|x_{o}^{*}(t), x_{j}^{*}(t)\right|, \Delta_{\min }=\min _{\forall j \in i} \min _{\forall t}\left|x_{o}^{*}(t), x_{j}^{*}(t)\right| .
\end{gathered}
$$

$\zeta$ is the distinguishing coefficient, $\zeta \in[0,1]$. Where, $x_{o}^{*}(t)=$ Reference sequence and $x_{i}^{*}(t)=$ Comparability sequence.

In the final step, the Grey Relational Grade is determined by using Equations (4) and (5) and its $\log S$ value is calculated for the higher is the better (H-T-B) concept.

$$
\begin{gathered}
\gamma\left(x_{o}^{(*)}, x_{i}^{(*)}\right)=\frac{1}{q} \sum_{t=1}^{q} \beta_{t} \gamma\left(x_{o}^{(*)}(t), x_{i}^{(*)}(t)\right) \\
\sum_{t=1}^{q} \beta_{t}=1
\end{gathered}
$$

where $q$ is the number of process responses. The Grey Relational Grade shows the interrelation between $x_{o}^{(*)}(t)$ and $x_{i}^{(*)}(t)$.

\subsection{Taguchi's Method}

Taguchi's Method is a technique usually used to frame-up the orthogonal array of experiments, with less variance between the experiment outcomes. This methodology not only helps to develop the orthogonal array but also minimize the numbers of experimental runs, enough to optimize and analyze the process. There are three kinds of signal-to-noise ratios: lower is the better (L-T-B), higher is the better (H-T-B), and nominal is the better (N-T-B), which is expressed in mathematical forms by Equations (6), (7) and (8). An ANOVA analysis is utilized for data-analysis to investigate the effect of main machining variables on the output responses.

Lower is the better (L-T-B),

$$
l_{i}=-10 \log \left[\frac{1}{n} \sum_{i=1}^{n} y_{i}^{2}\right]
$$

Higher is the better (H-T-B),

$$
l_{i}=-10 \log \left[\frac{1}{n} \sum_{i=1}^{n} \frac{1}{y_{i}^{2}}\right]
$$

Nominal is the better (N-T-B),

$$
l_{i}=-10 \log \left[\frac{1}{n s} \sum_{i=1}^{n} y_{i}^{2}\right]
$$

where $y_{i}$ is the measured output response at the $i^{\text {th }}$ trial, $n$ is the total number of experimental-runs, $l_{i}$ is the lossquality function at the $i^{\text {th }}$ trial and $\mathrm{s}$ denotes the standard deviation.

\subsection{Principal Component Analysis}

Principal Component Analysis was introduced by Pearson and Hotelling (1933). This methodology is utilized to define the variance and covariance relation with the help of linear composition of original parameters. The $\mathrm{PC}_{1}$ describes the maximal variance in the collected data and the $\mathrm{PC}_{2}$ describes the remaining variance that was left by the $\mathrm{PC}_{1}$ and so on. Suppose, the systemvariability is depicted by the p-components. The system variability may be described by a smaller number, $m$ $(m \leq p)$, of the PCs, i.e., $m$ PCs can account for the majority of variance within the original $p$ parameters.

For the response variables, $Z_{1}, Z_{2} \ldots Z_{\mathrm{p}}$, there is the following PCs $Y_{i}(i=1,2,3, \ldots, p)$.

$$
\begin{gathered}
Y_{1}=a_{11} Z_{1}+a_{12} Z_{2}+\ldots+a_{i p} Z_{p} \\
Y_{2}=a_{21} Z_{1}+a_{22} Z_{2}+\ldots+a_{2 p} Z_{p} \\
Y_{m}=a_{m 1} Z_{1}+a_{m 2} Z_{2}+\ldots+a_{m p} Z_{p}
\end{gathered}
$$

where $a_{m 1}^{2}+a_{m 2}^{2}+\ldots+a_{m p}^{2}=1$

Here, $Y_{1}$ is known as first principal component, $Y_{2}$ is known as the second principal component and so on. The $m^{\text {th }}$ component coefficient is the parts of the eigenvector matching to the $m^{\text {th }}$ biggest eigenvalues. The principal component analysis can be done on MINITAB software.

Principal Component Analysis is an effective methodology to describe the slight number of components that is responsible for the principal sources of variation in a set of correlated-quality characteristics.

The procedure of Principal Component Analysis is as follows:

a) Calculate the signal-to-noise ratio for every outputresponse by Equations (6) to (8).

b) Normalize the signal-to-noise ratio of every output responses into 0 to 1 by the use of Equations (1) and (2).

c) Carry out principal component analysis on the normalized data.

d) Determine the eigen-values, and eigen-vectors.

e) Calculate the numbers of PCs, m, and compute.

\subsection{Fuzzy Method}

In this methodology, the fuzzy reasoning grade $\left(\mathrm{FRG}_{0}\right)$ is calculated by the use of the max-min fuzzy interface and the centroid defuzzification methods. The system of Fuzzy Logic contains 5 components; Fuzzifier, Membership Function, Rules, Inference System, and Defuzzifier.

The fuzzy-logic-interface system for this research work is developed using MathWorks TM MATLAB ${ }^{\circledR}$ 8.1.0.604 (Release 2013a), Fuzzy Logic Toolbox. Here, the basic structure of the fuzzy logic unit for two fuzzy inputs with one fuzzy output is displayed in Figure 1.

Fuzzy linguistic description is the formal presentation of systems made through fuzzy IF-THEN rules. 


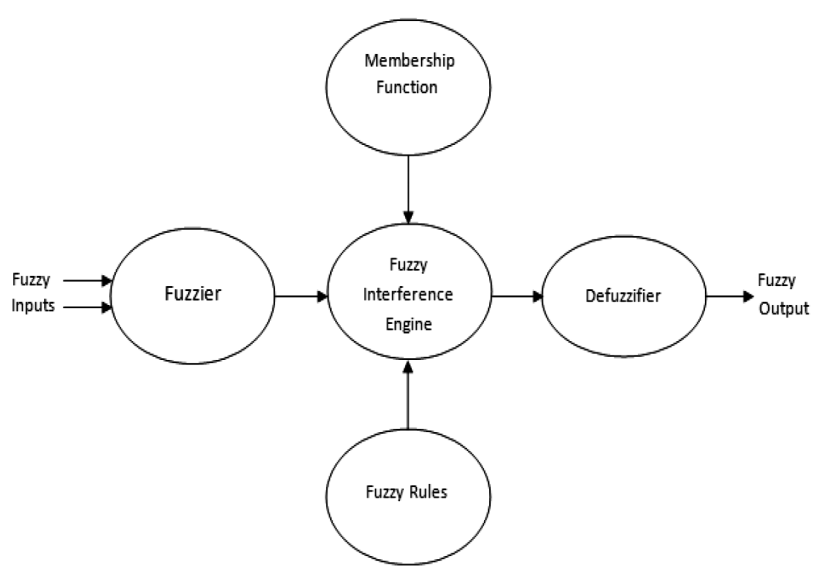

Figure 1: Basic structure of fuzzy logic unit

Rule one: IF $\left(Y_{1}\right.$ is $\left.E_{1}\right)$ and $\left(Y_{2}\right.$ is $\left.G_{1}\right)$ then $\left(Z\right.$ is $\left.F_{1}\right)$ else

Rule two: IF $\left(Y_{1}\right.$ is $\left.E_{2}\right)$ and $\left(Y_{2}\right.$ is $\left.G_{2}\right)$ then $\left(Z\right.$ is $\left.F_{2}\right)$ else

Rule twenty five: IF $\left(Y_{1}\right.$ is $\left.E_{25}\right)$ and $\left(Y_{2}\right.$ is $\left.G_{25}\right)$ then $(Z$ is $F_{25}$ ) else
$\mu_{E i}, \mu_{G i}$ and $\mu_{F i}$ are the membership functions corresponding to the $E_{i}, G_{i}$ and $F_{i}$ fuzzy subsets. In this research work, five fuzzy-subsets are allotted to two inputs and nine fuzzy subsets are allotted to the output as displayed in Figure 4. The total possible number of fuzzy rules used here is twenty-five. These fuzzy rules are obtained with the evidence that a bigger $\log \mathrm{S}$ value corresponds to the major benefit to the process output. Suppose, $Y_{1}$ and $Y_{2}$ are the values of the inputs, the membership function of the multi-output $Z$ can be displayed by Equation (9).

$$
\begin{aligned}
& \mu_{F_{0}}(Z)=\left(\mu_{E_{1}}\left(Y_{1}\right) \wedge \mu_{G_{1}}\left(Y_{2}\right) \wedge \mu_{F_{1}}(Z)\right) \ldots \vee \\
& \vee\left(\mu_{E_{n}}\left(Y_{1}\right) \wedge \mu_{G_{n}}\left(Y_{2}\right) \wedge \mu_{F_{n}}(Z)\right)
\end{aligned}
$$

Here, $\wedge$ is related to minimal and $\vee$ is related to maximal operation. For the defuzzification, centre-of-gravity methodology is used, which convert multi-output $\mu_{C_{0}}(Z)$ into crisp fuzzy reasoning grade $\left(F R G_{0}\right)$ using Equation (10).

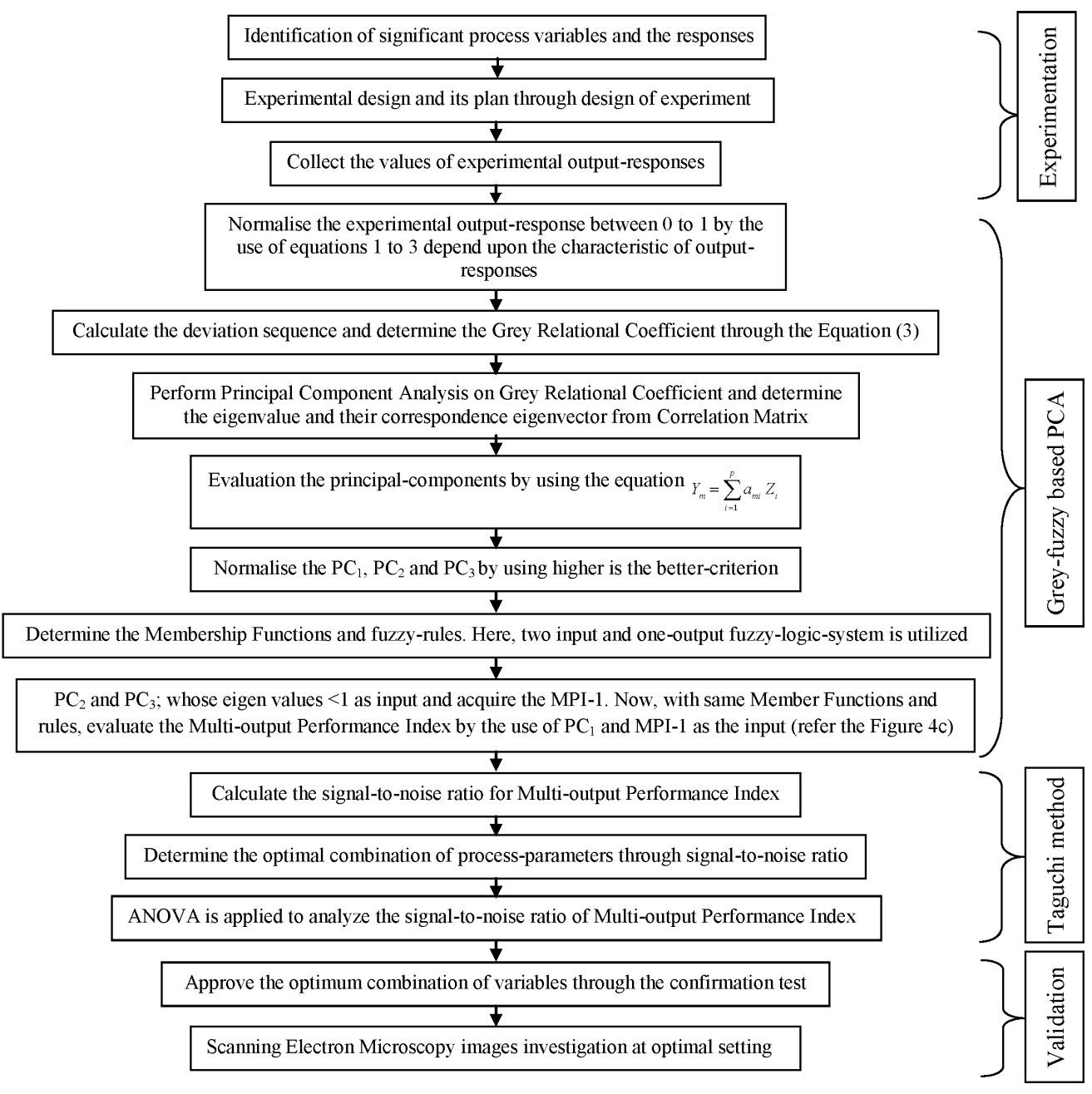

Figure 2: Methodology of Integrated Statistical Grey-Fuzzy-TM based PCA Approach 
M. MODI, G. AGARWAL: INTEGRATED STATISTICAL METHODOLOGY FOR OPTIMIZING THE MACHINING ...

$$
F R G_{0}=\frac{\sum Z \mu_{F_{0}}(Z)}{\sum \mu_{F_{0}}(Z)}
$$

\section{METHODOLOGY FOR AN INTEGRATED GREY-FUZZY-TAGUCHI-BASED APPROACH}

The detail procedure for an integrated Grey-FuzzyTaguchi-based PCA method is shown in Figure 2.

\section{EXPERIMENTAL PART}

Eighteen experiments were conducted according to Taguchi's $\mathrm{L}_{18}$ orthogonal array on in-house-designed and fabricated silicon carbide Powder Mixed-Electro Discharge Diamond Surface Grinding set-up. All the details of the Powder Mixed-Electro Discharge Diamond Surface Grinding set-up are available at Modi et al. ${ }^{17}$ The schematic-photographic diagram of Powder MixedElectro Discharge Diamond Surface Grinding frame-up is displayed in Figure 3.

The various input parameters like powder concentration $(\mathrm{gm} / \mathrm{L})$, current $(\mathrm{A})$, pulse-on-time $(\mu \mathrm{s})$, wheel-speed $\left(\mathrm{min}^{-1}\right)$ and duty cycle (DC) were selected for the experimental investigation. Depending upon the initial experimental results and Electrical Discharge Machining capacity, the variables range was selected as displayed in Table 1.

Table 1: Various input variables and their levels

\begin{tabular}{|c|l|c|c|c|}
\hline Symbol & \multicolumn{1}{|c|}{ Control Factor } & Level 1 & Level 2 & Level 3 \\
\hline$P-C$ & $\begin{array}{l}\text { SiC Powder Concentra- } \\
\text { tion }(\mathrm{gm} / \mathrm{L})\end{array}$ & 2 & 4 & - \\
\hline$I$ & Current $(\mathrm{A})$ & 1 & 5 & 9 \\
\hline$T_{\text {on }}$ & Pulse-on-time $(\mu \mathrm{s})$ & 100 & 150 & 200 \\
\hline$S$ & Wheel Speed $\left(\mathrm{min}^{-1}\right)$ & 350 & 550 & 750 \\
\hline$D C$ & Duty Cycle & 0.61 & 0.69 & 0.77 \\
\hline
\end{tabular}

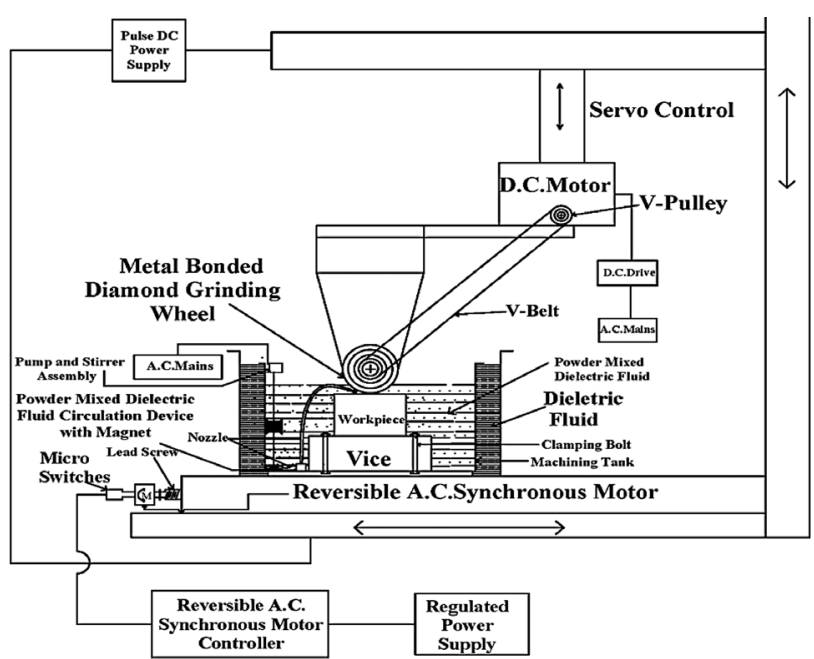

Figure 3: Schematic diagram of in-house-designed and fabricated Powder Mixed-Electro discharge diamond surface grinding set-up
The detailed description of the bronze-diamond wheel is displayed in Table 2.

Table 2: Detail description of bronze-diamond grinding wheel

\begin{tabular}{|c|c|c|c|c|c|c|c|}
\hline Abrasive & $\begin{array}{c}\text { Dia- } \\
\text { meter }\end{array}$ & $\begin{array}{c}\text { Thick- } \\
\text { ness }\end{array}$ & $\begin{array}{c}\text { Bond } \\
\text { mate- } \\
\text { rial }\end{array}$ & $\begin{array}{c}\text { Concen- } \\
\text { tration }\end{array}$ & Bore & $\begin{array}{c}\text { Depth } \\
\text { of } \\
\text { abra- } \\
\text { sive }\end{array}$ & $\begin{array}{c}\text { Grit } \\
\text { size }\end{array}$ \\
\hline Diamond & $\begin{array}{c}100 \\
\mathrm{~mm}\end{array}$ & $\begin{array}{c}10 \\
\mathrm{~mm}\end{array}$ & Bronze & $75 \%$ & $\begin{array}{c}32 \\
\mathrm{~mm}\end{array}$ & $\begin{array}{c}5 \\
\mathrm{~mm}\end{array}$ & $80 / 100$ \\
\hline
\end{tabular}

In this experimentation, the work-piece material was Ti6Al4V. The work-piece is flat and rectangular in shape. The composition of Ti-6Al-4V (grade-5) is Carbon $=0.02 \%, \mathrm{Al}=6.05 \%, \mathrm{Ti}=90.1 \%, \mathrm{~V}=3.7 \%$ and $\mathrm{Fe}=0.13 \%$. The silicon carbide powder is added into the dielectric fluid of the EDDSG set-up. The powder particle size is approximately \#30 $\mu \mathrm{m}$ and the concentration range is from $2 \mathrm{gm} /$ litre to $4 \mathrm{gm} / \mathrm{litre}$.

Equation (11) was used to calculate the material removal rate and wheel wear rate for each machining process.

$$
\frac{M R R}{W W R}(\mathrm{mg} / \mathrm{min})=\frac{D W W \times 100}{t}
$$

DWW is the difference in the work-piece/wheel weight before and after the machining time equal to 30 min. The material removal rate and wheel wear rate were measured by using the High Precision Electronic Balance, WENSAR, HPB-310 Model. The surface roughness of the machined work-piece was measured by the Surtronic-25 surface roughness tester at the cut-off value of $0.8 \mathrm{~mm}$. The digital tachometer was used for the grinding wheel speed measurement.

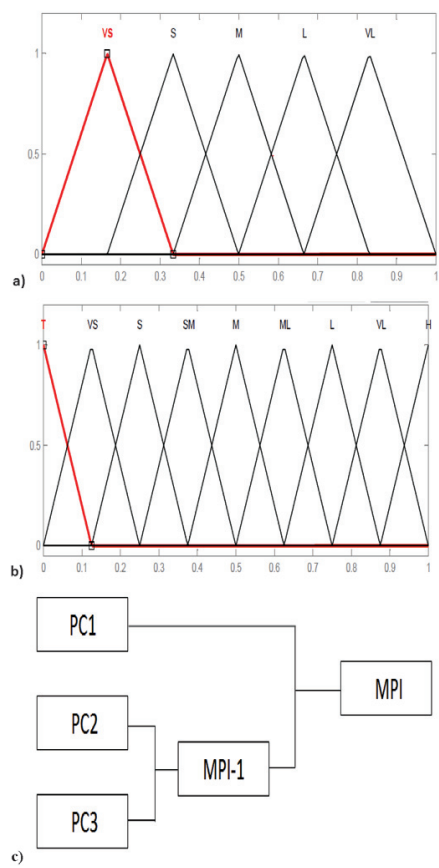

Figure 4: a) Membership function of inputs, b) Membership function of output, c) Fuzzy-Interface system at 2-level 
M. MODI, G. AGARWAL: INTEGRATED STATISTICAL METHODOLOGY FOR OPTIMIZING THE MACHINING ...

Table 3: $\mathrm{L}_{18}$ orthogonal array, output responses, $\log \mathrm{S}$ value, and normalised $\log \mathrm{S}$ value

\begin{tabular}{|c|c|c|c|c|c|c|c|c|c|c|c|c|c|c|}
\hline \multirow[b]{2}{*}{ Exp. No } & \multicolumn{5}{|c|}{ Control Factor } & \multicolumn{3}{|c|}{ Responses } & \multicolumn{3}{|c|}{$\log \mathrm{S}$ value } & \multicolumn{3}{|c|}{ Normalized $\log \mathrm{S}$ value } \\
\hline & $\mathrm{P}-\mathrm{C}$ & $I$ & $T_{\text {on }}$ & $S$ & $D C$ & $\begin{array}{c}M R R \\
(\mathrm{mg} / \mathrm{min})\end{array}$ & $\begin{array}{c}R_{\mathrm{a}} \\
(\mu \mathrm{m})\end{array}$ & $\begin{array}{c}\mathrm{WWR} \\
(\mathrm{gm} / \mathrm{min})\end{array}$ & MRR & $R_{\mathrm{a}}$ & WWR & MRR & $R_{\mathrm{a}}$ & WWR \\
\hline 1 & 1 & 1 & 1 & 1 & 1 & 1.50 & 1.54 & 0.0078 & 3.52 & -3.75 & 42.16 & 0.44 & 0.21 & 0.000 \\
\hline 2 & 1 & 1 & 2 & 2 & 2 & 1.60 & 1.33 & 0.0162 & 4.08 & -2.48 & 35.81 & 0.53 & 0.14 & 0.387 \\
\hline 3 & 1 & 1 & 3 & 3 & 3 & 1.52 & 1.01 & 0.0421 & 3.64 & -0.09 & 27.51 & 0.46 & 0.00 & 0.893 \\
\hline 4 & 1 & 2 & 1 & 1 & 2 & 1.66 & 3.34 & 0.0083 & 4.40 & -10.47 & 41.62 & 0.59 & 0.59 & 0.033 \\
\hline 5 & 1 & 2 & 2 & 2 & 3 & 1.84 & 4.61 & 0.0198 & 5.30 & -13.27 & 34.07 & 0.74 & 0.75 & 0.493 \\
\hline 6 & 1 & 2 & 3 & 3 & 1 & 1.55 & 3.52 & 0.0515 & 3.81 & -10.93 & 25.76 & 0.49 & 0.62 & 1.000 \\
\hline 7 & 1 & 3 & 1 & 2 & 1 & 2.20 & 5.98 & 0.0289 & 6.85 & -15.53 & 30.78 & 1.00 & 0.88 & 0.694 \\
\hline 8 & 1 & 3 & 2 & 3 & 2 & 1.65 & 5.37 & 0.0169 & 4.35 & -14.60 & 35.44 & 0.58 & 0.83 & 0.410 \\
\hline 9 & 1 & 3 & 3 & 1 & 3 & 1.75 & 6.94 & 0.0281 & 4.86 & -16.83 & 31.03 & 0.67 & 0.95 & 0.679 \\
\hline 10 & 2 & 1 & 1 & 3 & 3 & 1.59 & 1.40 & 0.0137 & 4.03 & -2.92 & 37.27 & 0.52 & 0.16 & 0.298 \\
\hline 11 & 2 & 1 & 2 & 1 & 1 & 1.11 & 1.05 & 0.0172 & 0.91 & -0.42 & 35.29 & 0.00 & 0.02 & 0.419 \\
\hline 12 & 2 & 1 & 3 & 2 & 2 & 1.23 & 1.40 & 0.0443 & 1.80 & -2.92 & 27.07 & 0.15 & 0.16 & 0.920 \\
\hline 13 & 2 & 2 & 1 & 2 & 3 & 1.86 & 5.86 & 0.0110 & 5.39 & -15.36 & 39.17 & 0.75 & 0.87 & 0.182 \\
\hline 14 & 2 & 2 & 2 & 3 & 1 & 1.52 & 4.07 & 0.0327 & 3.64 & -12.19 & 29.71 & 0.46 & 0.69 & 0.759 \\
\hline 15 & 2 & 2 & 3 & 1 & 2 & 1.45 & 2.33 & 0.0280 & 3.23 & -7.35 & 31.06 & 0.39 & 0.41 & 0.677 \\
\hline 16 & 2 & 3 & 1 & 3 & 2 & 1.60 & 5.76 & 0.0104 & 4.08 & -15.21 & 39.66 & 0.53 & 0.86 & 0.152 \\
\hline 17 & 2 & 3 & 2 & 1 & 3 & 1.42 & 6.63 & 0.0088 & 3.05 & -16.43 & 41.11 & 0.36 & 0.93 & 0.064 \\
\hline 18 & 2 & 3 & 3 & 2 & 1 & 1.88 & 7.65 & 0.0146 & 5.48 & -17.67 & 36.71 & 0.77 & 1.00 & 0.332 \\
\hline
\end{tabular}

\section{PROCESSING OF EXPERIMENTAL DATA}

Here, Table 3 displays the $\mathrm{L}_{18}$ orthogonal array, output responses, $\log \mathrm{S}$ value, and normalised $\log \mathrm{S}$ value. Table 4 displays the deviation sequence and Grey Relational Coefficient. Table 5 displays the eigenvalues, eigenvector. Table 6 displays the fuzzy rules. Table 7 displays the principal components and multi-output performance index and Table $\mathbf{8}$ displays the response and ANOVA for multi-output performance index.

Figure 5 displays the fuzzy logic reasoning procedure for the test result 8; Figure 6 displays the surface plot of multi-output performance index with inputs; Fig-

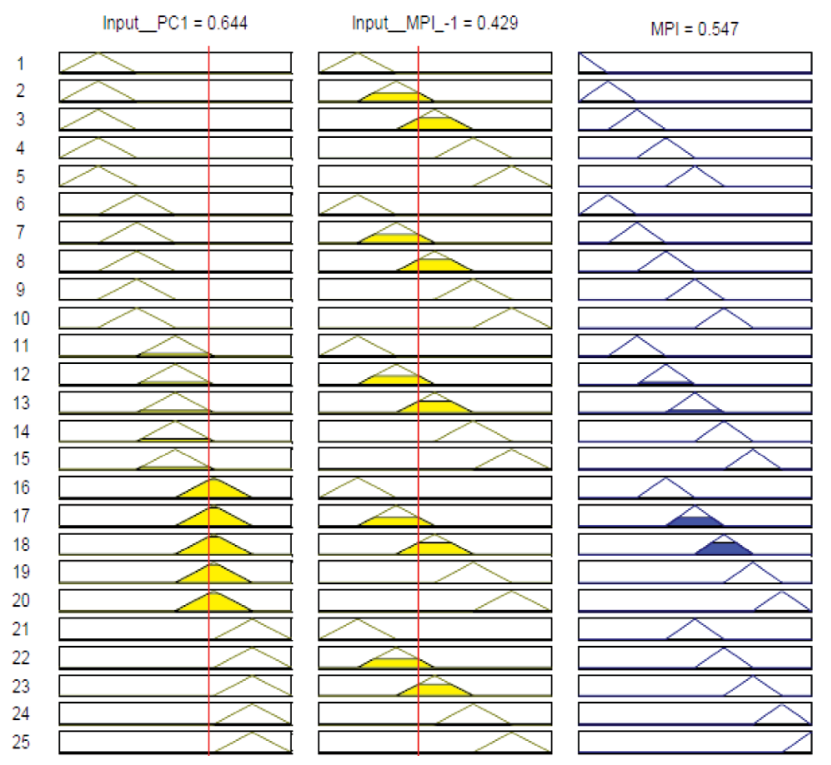

Figure 5: Fuzzy logic reasoning procedure for the test result 8 ure 7 displays the $\%$ contribution of machining processparameters on multi-output performance index, and Figure 8 displays the signal to noise-ratio plot of multioutput performance index.

Calculation of the deviation sequence and Grey Relational Coefficient (GRC).

Table 4: Displays the deviation sequence and GRC

\begin{tabular}{|c|c|c|c|c|c|c|}
\hline $\begin{array}{c}\text { Exp. } \\
\text { No. }\end{array}$ & \multicolumn{2}{|c|}{ Deviation sequence } & \multicolumn{3}{c|}{ GRC } \\
\hline & MRR & $R_{\mathrm{a}}$ & WWR & MRR & $R_{\mathrm{a}}$ & WWR \\
\hline 1 & 0.560 & 0.792 & 1.000 & 0.472 & 0.387 & 0.333 \\
\hline 2 & 0.466 & 0.864 & 0.613 & 0.518 & 0.367 & 0.449 \\
\hline 3 & 0.541 & 1.000 & 0.107 & 0.480 & 0.333 & 0.824 \\
\hline 4 & 0.412 & 0.409 & 0.967 & 0.548 & 0.550 & 0.341 \\
\hline 5 & 0.262 & 0.250 & 0.507 & 0.657 & 0.667 & 0.497 \\
\hline 6 & 0.512 & 0.383 & 0.000 & 0.494 & 0.566 & 1.000 \\
\hline 7 & 0.000 & 0.122 & 0.306 & 0.999 & 0.805 & 0.620 \\
\hline 8 & 0.421 & 0.175 & 0.590 & 0.543 & 0.741 & 0.459 \\
\hline 9 & 0.335 & 0.048 & 0.321 & 0.599 & 0.913 & 0.609 \\
\hline 10 & 0.475 & 0.839 & 0.702 & 0.513 & 0.373 & 0.416 \\
\hline 11 & 1.001 & 0.981 & 0.581 & 0.333 & 0.338 & 0.463 \\
\hline 12 & 0.850 & 0.839 & 0.080 & 0.370 & 0.373 & 0.862 \\
\hline 13 & 0.246 & 0.132 & 0.818 & 0.670 & 0.792 & 0.379 \\
\hline 14 & 0.541 & 0.312 & 0.241 & 0.480 & 0.616 & 0.675 \\
\hline 15 & 0.610 & 0.587 & 0.323 & 0.451 & 0.460 & 0.608 \\
\hline 16 & 0.466 & 0.140 & 0.848 & 0.518 & 0.781 & 0.371 \\
\hline 17 & 0.640 & 0.071 & 0.936 & 0.438 & 0.876 & 0.348 \\
\hline 18 & 0.230 & 0.000 & 0.668 & 0.685 & 1.000 & 0.428 \\
\hline & & & & & & \\
\hline
\end{tabular}

Principal Component Analysis for eigenvalue and eigenvector. 
Table 5: Displays the eigenvalues, and eigenvector

\begin{tabular}{|c|c|c|c|}
\hline & $\mathrm{PC}_{1}$ & $\mathrm{PC}_{2}$ & $\mathrm{PC}_{3}$ \\
\hline Eigenvalue & 1.6666 & 0.9246 & 0.4089 \\
\hline \multirow{2}{*}{ Eigenvector } & $\begin{array}{c}0.640,0.681, \\
-0.354]\end{array}$ & $\begin{array}{c}-0.383,0.117, \\
0.916]\end{array}$ & {$\left[\begin{array}{c}-0.666,0.722, \\
0.186]\end{array}\right.$} \\
\hline Proportion & 0.556 & 0.308 & 0.136 \\
\hline Cumulative & 0.556 & 0.864 & 1.000 \\
\hline
\end{tabular}

Primarily, the principal components (PCs) are divided into two categories with eigenvalue $>1$ and eigenvalue $<1$. MPI-1 is calculated through $\mathrm{PC}_{2}$ and $\mathrm{PC}_{3}$ as input with eigenvalue $<1$. Final multi-output performance index is calculated through $\mathrm{PC}_{1}$ and MPI- 1 as the input by using the similar membership functions and rules.

Table 6: Twenty-five fuzzy rules in tabular form

\begin{tabular}{|c|c|c|c|c|c|c|}
\hline \multirow{2}{*}{ MPI } & \multicolumn{9}{|c|}{ Input 1 } \\
\cline { 2 - 7 } & $\mathrm{VS}$ & $\mathrm{S}$ & $\mathrm{M}$ & $\mathrm{L}$ & \multicolumn{2}{|c|}{ VL } \\
\hline \multirow{4}{*}{ Input 2 } & $\mathrm{VS}$ & $\mathrm{T}$ & $\mathrm{VS}$ & $\mathrm{S}$ & $\mathrm{SM}$ & $\mathrm{M}$ \\
\cline { 3 - 7 } & $\mathrm{S}$ & $\mathrm{VS}$ & $\mathrm{S}$ & $\mathrm{SM}$ & $\mathrm{M}$ & $\mathrm{ML}$ \\
\cline { 3 - 7 } & $\mathrm{S}$ & $\mathrm{S}$ & $\mathrm{SM}$ & $\mathrm{M}$ & $\mathrm{ML}$ & $\mathrm{L}$ \\
\cline { 3 - 7 } & $\mathrm{L}$ & $\mathrm{SM}$ & $\mathrm{M}$ & $\mathrm{ML}$ & $\mathrm{L}$ & $\mathrm{VL}$ \\
\cline { 3 - 7 } & $\mathrm{VL}$ & $\mathrm{M}$ & $\mathrm{ML}$ & $\mathrm{L}$ & $\mathrm{VL}$ & $\mathrm{H}$ \\
\hline
\end{tabular}

The Fuzzy logic reasoning procedure for the test result 8 is displayed in Figure 5. The surface plot of the multi-output performance index is displayed in Figure 6.

Calculation of multi-output performance index (MPI).

\section{RESULTS AND DISCUSSION}

The ANOVA test was performed on the multi-output performance index. The influence of various machining process parameters on the multi-output performance index and the ANOVA analysis result is displayed in Table 8. The optimum combination of various process parameters obtained through the integrated statistical optimization method for the multi-output optimization in Powder Mixed-Electro Discharge Diamond Surface Grinding of Ti6Al4V, is powder concentration with level one; current with level three; pulse-on-time with level three; the speed with level two and duty cycle with level three. For the validation test, one additional confirmation experiment was performed on this set-up according to
Table 7: Principal Components and multi-output performance index (MPI)

\begin{tabular}{|c|c|c|c|c|c|c|c|c|}
\hline \multirow{2}{*}{$\begin{array}{c}\text { Exp. } \\
\text { no. }\end{array}$} & \multicolumn{3}{|c|}{$\begin{array}{c}\text { Principal } \\
\text { components }\end{array}$} & \multicolumn{3}{|c|}{ Normalise PCs } & \multirow[t]{2}{*}{ MPI-1 } & \multirow[t]{2}{*}{ MPI } \\
\hline & $\mathrm{PC}_{1}$ & $\mathrm{PC}_{2}$ & $\mathrm{PC}_{3}$ & $\mathrm{PC}_{1}$ & $\mathrm{PC}_{2}$ & $\mathrm{PC}_{3}$ & & \\
\hline 1 & 0.448 & 0.531 & 0.027 & 0.335 & 0.000 & 0.059 & 0.500 & 0.379 \\
\hline 2 & 0.423 & 0.653 & 0.003 & 0.302 & 0.190 & 0.000 & 0.500 & 0.348 \\
\hline 3 & 0.242 & 0.978 & 0.073 & 0.072 & 0.698 & 0.175 & 0.417 & 0.188 \\
\hline 4 & 0.605 & 0.587 & 0.095 & 0.535 & 0.087 & 0.230 & 0.103 & 0.285 \\
\hline 5 & 0.699 & 0.785 & 0.136 & 0.656 & 0.397 & 0.332 & 0.300 & 0.458 \\
\hline 6 & 0.348 & 1.171 & 0.265 & 0.207 & 1.001 & 0.652 & 0.500 & 0.287 \\
\hline 7 & 0.968 & 1.045 & 0.031 & 1.000 & 0.803 & 0.069 & 0.464 & 0.500 \\
\hline 8 & 0.690 & 0.715 & 0.258 & 0.644 & 0.288 & 0.637 & 0.429 & 0.547 \\
\hline 9 & 0.790 & 0.894 & 0.373 & 0.772 & 0.567 & 0.922 & 0.809 & 0.875 \\
\hline 10 & 0.435 & 0.621 & 0.005 & 0.319 & 0.141 & 0.004 & 0.060 & 0.124 \\
\hline 11 & 0.279 & 0.591 & 0.108 & 0.119 & 0.094 & 0.262 & 0.112 & 0.042 \\
\hline 12 & 0.186 & 0.975 & 0.182 & 0.000 & 0.694 & 0.447 & 0.609 & 0.500 \\
\hline 13 & 0.834 & 0.696 & 0.196 & 0.829 & 0.258 & 0.481 & 0.298 & 0.591 \\
\hline 14 & 0.488 & 0.874 & 0.250 & 0.386 & 0.536 & 0.616 & 0.617 & 0.503 \\
\hline 15 & 0.387 & 0.783 & 0.144 & 0.257 & 0.395 & 0.352 & 0.322 & 0.191 \\
\hline 16 & 0.732 & 0.630 & 0.288 & 0.698 & 0.154 & 0.710 & 0.414 & 0.594 \\
\hline 17 & 0.754 & 0.589 & 0.405 & 0.726 & 0.091 & 1.003 & 0.500 & 0.675 \\
\hline 18 & 0.968 & 0.771 & 0.345 & 1.000 & 0.376 & 0.853 & 0.662 & 0.500 \\
\hline
\end{tabular}

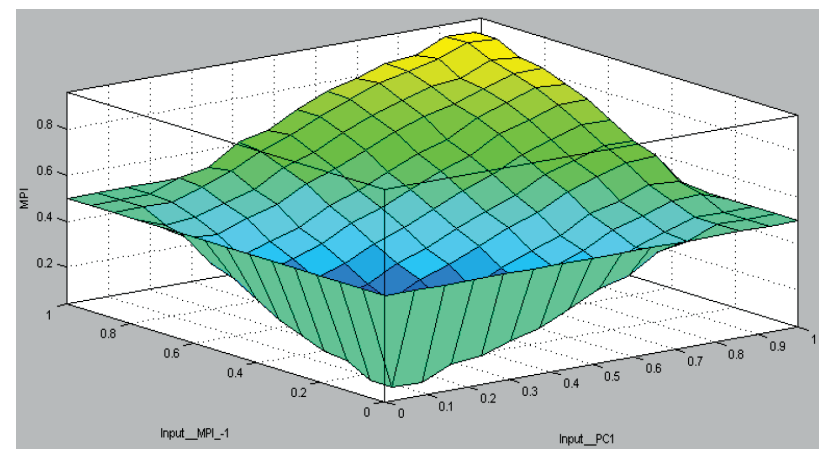

Figure 6: Surface Plot of MPI with inputs

the derived optimal condition and the outcomes of the result showed satisfactory matching between predicted and experimented results. The confirmation test result is listed in Table 9, which displays the closure correlation between the experimental and predicted values.

A Scanning Electron Microscopy investigation has been conducted on the produced machine surface through silicon carbide powder mixed-Electro Discharge Diamond Surface Grinding process under optimal condi-

Table 8: Response and ANOVA for multi-output performance index (MPI)

\begin{tabular}{|c|c|c|c|c|c|c|c|c|c|c|}
\hline \multicolumn{4}{|c|}{ Response table } & \multirow{2}{*}{ Symbol } & \multicolumn{6}{|c|}{ ANOVA table } \\
\hline Level 1 & Level 2 & Level 3 & Max-Min & & DF & SS & MS & $\mathrm{F}$ & $\mathrm{P}$ & $\mathrm{C}(\%)$ \\
\hline$-8.118^{\mathrm{p}}$ & -10.062 & & 1.945 & $\mathrm{P}-\mathrm{C}$ & 1 & 0.001200 & 0.001200 & 0.03 & 0.860 & 0.258 \\
\hline-13.967 & -8.907 & $-4.397 \mathrm{p}$ & 9.570 & $\mathrm{I}$ & 2 & 0.382457 & 0.191229 & 5.26 & 0.035 & 82.47 \\
\hline-8.763 & -9.685 & $-8.823^{p}$ & 0.922 & $\mathrm{~T}_{\mathrm{ON}}$ & 2 & 0.000869 & 0.000435 & 0.01 & 0.988 & 0.187 \\
\hline-10.970 & $-6.430^{p}$ & -9.871 & 4.540 & $\mathrm{~S}$ & 2 & 0.037324 & 0.018662 & 0.51 & 0.617 & 8.049 \\
\hline-10.802 & -8.373 & $-8.096^{p}$ & 2.707 & $\mathrm{DC}$ & 2 & 0.041857 & 0.020929 & 0.58 & 0.584 & 9.026 \\
\hline & & & & Error & 8 & 0.291024 & 0.036378 & & & \\
\hline & & & & Total & 17 & 0.754733 & & & & \\
\hline
\end{tabular}




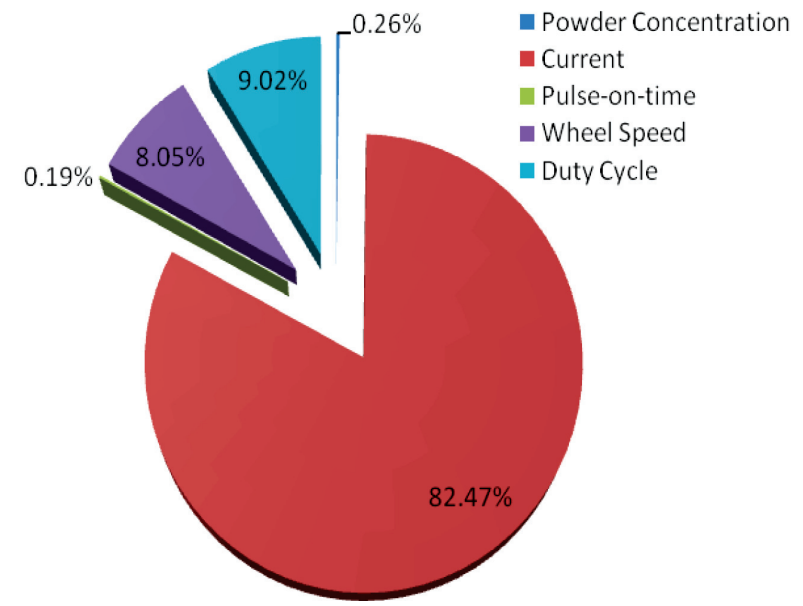

Figure 7: Percentage contribution of machining process parameters on MPI

Table 9: Result of confirmation test

\begin{tabular}{|c|c|c|c|}
\hline \multirow{2}{*}{ Factor Level } & $\begin{array}{c}\text { Initial Process } \\
\text { Parameters }\end{array}$ & \multicolumn{2}{|c|}{ Optimal Process parameter } \\
\cline { 2 - 4 } & $P C_{1} I_{1} T_{\mathrm{on}_{1}} S_{1} D_{1}$ & $P C_{1} I_{3} T_{\mathrm{on}_{3}} S_{2} D_{3}$ & $P C_{1} I_{3} T_{\mathrm{on}_{3}} S_{2} D_{3}$ \\
\hline $\begin{array}{c}\mathrm{MRR} \\
(\mathrm{mg} / \mathrm{min})\end{array}$ & 1.50 & - & 1.86 \\
\hline$R_{\mathrm{a}}(\mu \mathrm{m})$ & 1.54 & - & 6.00 \\
\hline $\begin{array}{c}\mathrm{WWR} \\
(\mathrm{gm} / \mathrm{min})\end{array}$ & 0.0078 & - & 0.024 \\
\hline $\mathrm{MPI}$ & 0.379 & 0.739 & 0.754 \\
\hline \multicolumn{4}{|c}{ Improvement in MPI is 0.375} \\
\hline
\end{tabular}

tions. Figure 9 displays the SEM image of the: a) produced machined surface at optimum condition $(I=9 \mathrm{~A}$, $T_{\text {on }}=200 \mu \mathrm{s}, D C=0.77, S=550 \mathrm{~min}^{-1}, P-C=2 \mathrm{gm}$ of powder/L); b) White recast layer thickness at optimum condition $\left(I=9 \mathrm{~A}, T_{\mathrm{on}}=200 \mu \mathrm{s}, D C=0.77, S=550\right.$ RPM, $P-C=2$ gm of powder/L). These images revealed that satisfactory output-responses are acquired through the suggested integrated statistical methodology.

\subsection{Confirmation test}

The estimated grade

$$
\hat{\gamma}=\gamma_{m}+\sum_{i=1}^{n}\left(\bar{\gamma}_{i}-\gamma_{m}\right)
$$

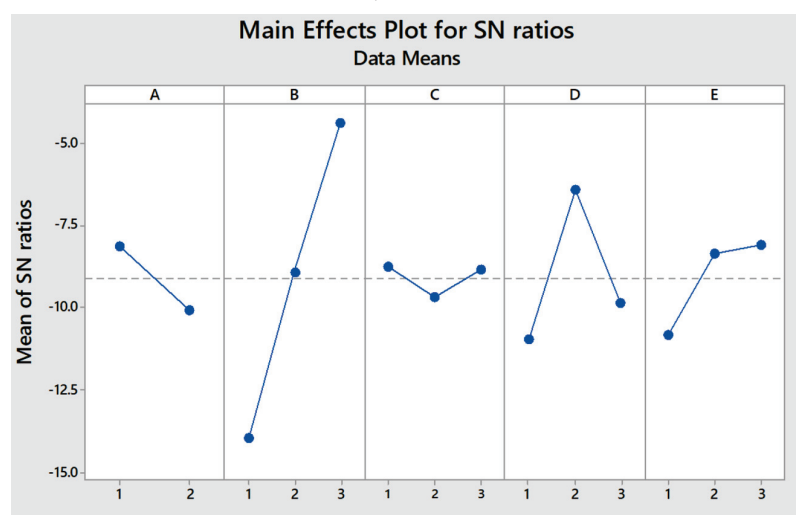

Figure 8: S/N-ratio plot of MPI
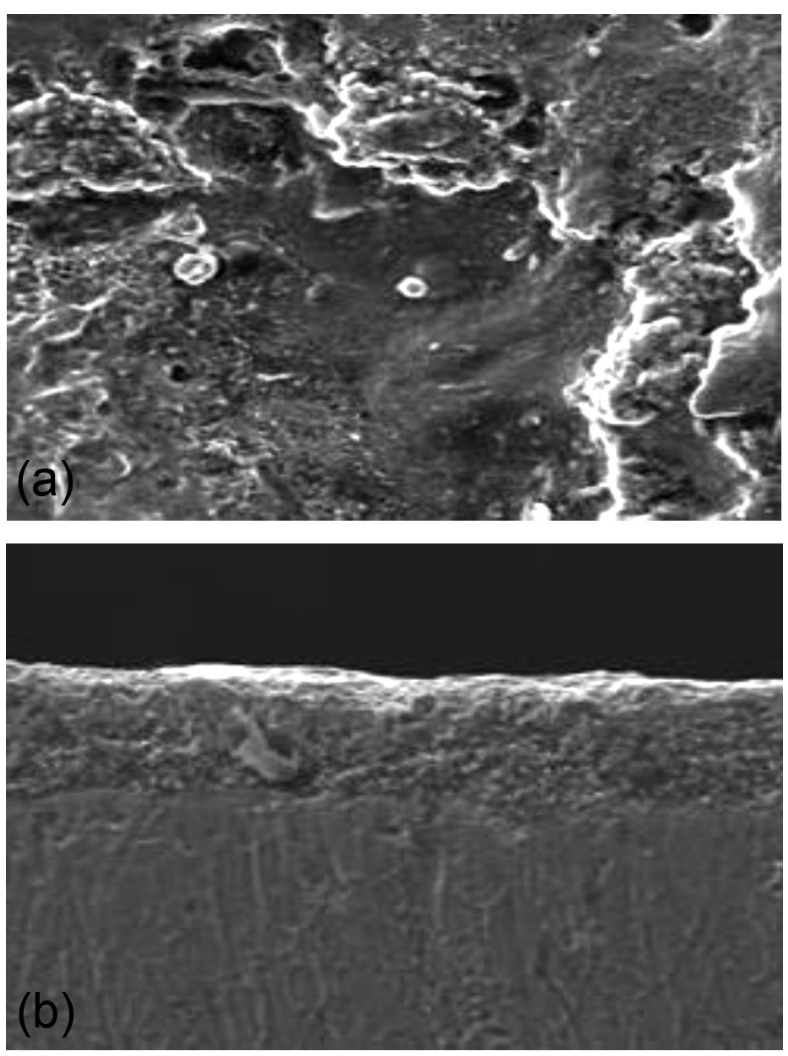

Figure 9: a) SEM image of the produced machined surface in Powder Mixed - EDDSG process with SiC powder under optimum conditions $\left(I=9 \mathrm{~A}, T_{\mathrm{on}}=200 \mu \mathrm{s}, D C=0.77, S=550 \mathrm{~min}^{-1}, P-C=2 \mathrm{gm}\right.$ of powder/L), b) SEM image of wrlt thickness with SiC powder under optimum conditions $\left(I=9 \mathrm{~A}, T_{\text {on }}=200 \mu \mathrm{s}, D C=0.77, S=550 \mathrm{~min}^{-1}\right.$, $P-C=2 \mathrm{gm}$ of powder/L).

where $\gamma_{\mathrm{m}}$ is the average grade, $\bar{\gamma}_{i}$ is the optimum level average grade and ' $n$ ' is the total significant design variables that affect the multi-output response. To ensure the enhancement in quality performance, a confirmation test is performed. The outcome of this test is displayed in Table 9.

\section{CONCLUSIONS}

In this research paper, an integrated statistical methodology of Grey-Fuzzy-Taguchi's Method based principal component analysis has been utilized for multi-output optimization of the machining parameters in silicon carbide powder mixed-Electro Discharge Diamond Surface Grinding processes of Ti6Al4V. The single multi-output performance index is calculated by the aggregation of all multi-responses through Grey-Fuzzy-Taguchi's Methodbased principal component analysis function. Hence, ANOVA is applied on multi-output performance index to calculate the signal-to-noise ratio with Higher is the Better criterion.

The following conclusions could be drawn based on the analysis of outcomes obtained through the suggested approach and SEM image investigations: 
1. The optimal level of machining process parameters derived from the integrated statistical methodology of Grey-Fuzzy-Taguchi's Method-based principal component analysis approach are: $2 \mathrm{gm} / \mathrm{L}$ of powder concentration; 9 A of current; $200 \mu$ s of pulse-on-time; 550 revolution per $\min \left(\mathrm{min}^{-1}\right)$ of wheel speed and 0.77 of duty cycle.

2. The experimental results of output responses under optimal condition are material removal rate equal to 1.86 $\mathrm{mg} / \mathrm{min} ; R_{\mathrm{a}}$ equal to $6.00 \mu \mathrm{m}$; and wheel wear rate equal to $0.024 \mathrm{gm} / \mathrm{min}$.

3. It is observed through ANOVA results that the percentage contribution of various process parameters on the process performance is powder concentration $(0.26 \%)$; current $(82.47 \%)$; pulse-on-time $(0.19 \%)$; wheel speed $(8.05 \%)$; and duty cycle $(9.02 \%)$. The current is the most significant parameter that affects the process performance.

4. The Multi-output Performance Index has been improved by 0.375 .

5. The SEM outcomes also equally satisfy the predicted outcomes from the suggested integrated statistical methodology.

The suggested integrated statistical method may also be utilized to optimize the problem of the co-occurring optimization of multi-correlated responses in some other production machining processes to improve the production efficiency and also automate the production machining process based on the calculated optimum values.

\section{Nomenclature}

\begin{tabular}{|c|c|}
\hline ANOVA & Analysis of variance \\
\hline PM-EDDSG & Powder Mixed-Electro \\
\hline & Diamond Surface Grinding \\
\hline $\mathrm{HM}$ & Hybrid Machining \\
\hline EDG & Electro Discharge Grinding \\
\hline EDM & Electrical Discharge Machining \\
\hline HMP & Hybrid Machining Process \\
\hline RSM & Response Surface Methodology \\
\hline DC & Duty Cycle (\%) \\
\hline DWW & $\begin{array}{l}\text { Difference in work-piece/wheel weight } \\
\text { before and after the machining }\end{array}$ \\
\hline WEDM & Wire Electrical Discharge Machining \\
\hline$I$ & Current (A) \\
\hline MRR & Material Removal Rate (mg/min) \\
\hline WWR & Wheel Wear Rate \\
\hline$R_{\mathrm{a}}$ & Average Roughness of Surface $(\mu \mathrm{m})$ \\
\hline $\mathrm{MIN}^{-1}$ & Revolution per minute \\
\hline$S$ & Wheel Speed $\left(\mathrm{MIN}^{-1}\right)$ \\
\hline$T_{\text {on }}$ & Pulse on-time $(\mu \mathrm{s})$ \\
\hline$t$ & Time in min \\
\hline$\rho$ & Density of work-piece material $\left(\mathrm{gm} / \mathrm{cm}^{3}\right)$ \\
\hline $\mathrm{P}-\mathrm{C}$ & Powder Concentration \\
\hline $\mathrm{OA}$ & Orthogonal Array \\
\hline $\mathrm{CM}$ & Correlation Matrix \\
\hline GRA & Grey Relational Analysis \\
\hline
\end{tabular}

$\begin{array}{ll}\text { PCA } & \text { Principal Component Analysis } \\ a_{\mathrm{mp}} & m_{\text {th }} \text { element in the } p_{\text {th }} \text { eigen vector } \\ \text { TU-Theory } & \text { Taguchi's Utility Theory } \\ \text { OQI } & \text { Overall Quality Index } \\ \text { H-T-B } & \text { Higher is the better Criterion } \\ \text { L-T-B } & \text { Lower is the better Criterion } \\ \text { N-T-B } & \text { Nominal is the better Criterion } \\ \text { GRC } & \text { Grey Relational Coefficient } \\ \text { GRG } & \text { Grey Relational Grade } \\ \text { TM } & \text { Taguchi's Method } \\ \text { PC/PCS } & \text { Principal Component / Principal Compo- } \\ & \text { nents } \\ \text { MF/MF } & \text { Membership Function/Membership Func- } \\ & \text { tions } \\ \text { MPI } & \text { Multi-output Performance Index }\end{array}$

\section{REFERENCES}

${ }^{1}$ J. L. Lin, K. S. Wang, B. H. Yan, Y. S. Tarng, Optimization of the electrical discharge machining process based on the Taguchi method with fuzzy logics, Journal of Materials Processing Technology, 102 (2000), 48-55, doi:10.1016/S0924-0136(00)00438-6

${ }^{2}$ K. Y. Kung, J. T. Horng, K. T. Chiang, Material removal rate and electrode wear ratio study on the powder mixed electrical discharge machining of cobalt-bonded tungsten carbide, Int J Adv Manuf Technol., 40 (2009), 95-104, doi:10.1007/s00170-007-1307-2

${ }^{3}$ G. K. Singh, V. Yadava, R. Kumar, Diamond face grinding of WC-Co composite with spark assistance: Experimental study and parameter optimization, International Journal of Precision Engineering and Manufacturing, 11 (2010) 4, 509-518, doi:10.1007/ s12541-010-0059-3

${ }^{4}$ J. L. Lin, C. L. Lin, The use of orthogonal array with grey relational analysis to optimize the electrical discharge machining process with multiple performance characteristics, International Journal of Machine Tools \& Manufacture, 42 (2002), 237-244, doi:10.1016/ S0890-6955(01)00107-9

${ }^{5}$ Y. S. Tarng, W. H. Yang, Application of the Taguchi method to the optimization of the submerged arc welding process, Materials and Manufacturing Processes, 13 (1998) 3, 455-467, doi:10.1080/ 10426919808935262

${ }^{6}$ T. C. Ko, J. L. Lin, C. L. Lin, Optimization of the EDM process based on the orthogonal array with fuzzy logic and grey relational analysis method, Int J Adv Manuf Technol., 19 (2002), 271-277, doi:10.1007/s001700200034

${ }^{7}$ Y. F. Tzeng, F. C. Chen, Multi-objective optimization of high-speed electrical discharge machining process using a Taguchi fuzzy-based approach, Material and Design, 28 (2007), 1159-1168, doi:10.1016/ j.matdes.2006.01.028

${ }^{8}$ J. L. Lin, C. L. Lin, The use of grey-fuzzy logic for the optimization of the manufacturing process, Journal of Materials Processing Technology, 160 (2005), 9-14, doi:10.1016/j.jmatprotec.2003.11.040

${ }^{9}$ P. M. George, B. K. Raghunath, L. M. Manocha, A. M. Warrier, EDM machining of carbon-carbon composite - a Taguchi approach, Journal of Materials Processing Technology, 145 (2004), 66-71, doi:10.1016/S0924-0136(03)00863-X

${ }^{10}$ C. P. Fung, P. C. Kang, Multi-response optimization in friction properties of PBT composites using Taguchi method and principle component analysis, Journal of Materials Processing Technology, 170 (2005), 602-610, doi:10.1016/j.jmatprotec.2005.06.040

${ }^{11}$ N. Alagumurthi, K. Palaniradja, V. Soundararajan, Optimization of grinding process through design of experiment (doe) - a comparative study, Materials and Manufacturing Processes, 21 (2006), 19-21, doi:0.1081/AMP-200060605 
${ }^{12}$ M. D. Jean, J. T. Wang, Using a principal components analysis for developing a robust design of electron beam welding, Int $\mathrm{J}$ Adv Manuf Technol., 28 (2006), 882-889, doi:10.1007/s00170-0042219-z

${ }^{13}$ S. Datta, S. S. Mahapatra, Modeling, simulation and parametric optimization of wire EDM process using response surface methodology coupled with grey-Taguchi technique, International Journal of Eng. Science and Technology, 2 (2010) 5, 162-183, doi:10.4314/ ijest.v2i5.60144

${ }^{14}$ S. D. Lahane, M. K. Rodge, S. B. Sharma, Multi-response optimization of wire-EDM process using principal component analysis, IOSR Journal of Engineering, 2 (2012) 8, 38-47

${ }^{15}$ V. K. Jain, Advanced Machining Processes, Allied Publishers Pvt. Ltd., New Delhi 2002

${ }^{16}$ J. L. Deng, Introduction to Grey system theory, J. Grey Syst., 1 (1989) $1,1-24$

${ }^{17}$ M. Modi, G. Agarwal, Powder-mixed electro-discharge diamond surface grinding process: modelling, comparative analysis and multioutput optimisation using weighted principal components analysis, SV-JME, 59 (2013), 735-747, doi:10.5545/sv-jme.2013.1146 